\title{
Unusual communication of an embedded peritoneal dialysis catheter with the colon before use: a case report with literature review
}

Takaya Handa ${ }^{1,2^{*}}$, Hiroyuki Suzuki ${ }^{2}$, Hiroyuki Matsubara ${ }^{3,4}$, Hiroaki Terajima ${ }^{4}$ and Tatsuo Tsukamoto²

\begin{abstract}
Background: Bowel perforation in peritoneal dialysis (PD) is mainly caused during the perioperative period. Delayed bowel perforation is difficult to diagnose because of its heterogenous clinical signs and rarity. Previously, the methods to diagnose delayed bowel perforation were invasive, but computed tomography $(C T)$ peritoneography is now employed as a less invasive method. There have been no literature reviews on delayed bowel perforation, including recent cases using CT peritoneography. Delayed bowel perforation before PD initiation has rarely been reported and was mostly after PD initiation. Here, we present a case and literature review of delayed bowel perforation before PD initiation possibly caused by mechanical compression of the PD catheter implanted by the Moncrief-Popovich technique.
\end{abstract}

Case presentation: A PD catheter was embedded in a 57-year-old woman with autosomal-dominant polycystic kidney disease, with the distal end of the PD catheter buried under the skin. She had no gastrointestinal symptoms, except renal failure progression, during conservative therapy. Nine months later, she was admitted to our hospital to exteriorize the distal end of the PD catheter. Immediately after the first PD solution was infused into her abdomen, she complained of watery diarrhea. CT peritoneography revealed an outflow of contrast media through the PD catheter into the luminal side of the sigmoid colon, suggesting an interaction between the PD catheter and the colon. Laparoscopic examination revealed that the lateral side of the PD catheter ( $5 \mathrm{~cm}$ from the catheter tip) had adhered to the sigmoid colon and that a small orifice had formed where the side hole of the catheter was attached to the colon. The lesion was entirely surrounded by fibrous tissue that prevented leakage of the intraluminal contents. After restoring the colon with a colostomy, the patient was treated with hemodialysis. Seven months later, she underwent closure of the colostomy.

Conclusions: Although perforation of the colon by a PD catheter through the side hole is very rare, it is important to consider the interaction of dialysis fluid with the gut if diarrhea or abdominal pain occurs after PD initiation. CT peritoneography may be helpful in identifying the bowel perforation site with minimal invasiveness.

Keywords: Peritoneal dialysis, Bowel perforation, Computed tomography peritoneography, Peritoneal dialysis catheter

\footnotetext{
* Correspondence: idatenpenging@gmail.com

'Department of Nephrology, Graduate School of Medicine, Kyoto University,

Kyoto, Japan

${ }^{2}$ Department of Nephrology and Dialysis, Kitano Hospital, Tazuke Kofukai

Medical Research Institute, Osaka, Japan

Full list of author information is available at the end of the article
}

(c) The Author(s). 2019 Open Access This article is distributed under the terms of the Creative Commons Attribution 4.0 International License (http://creativecommons.org/licenses/by/4.0/), which permits unrestricted use, distribution, and reproduction in any medium, provided you give appropriate credit to the original author(s) and the source, provide a link to the Creative Commons license, and indicate if changes were made. The Creative Commons Public Domain Dedication waiver (http://creativecommons.org/publicdomain/zero/1.0/) applies to the data made available in this article, unless otherwise stated. 


\section{Background}

Peritoneal dialysis (PD) is a widely accepted modality in renal replacement therapy for end-stage renal disease. Management of PD catheter-associated infections is essential for the successful performance and continuation of PD therapy. To reduce infectious complications, such as exit-site and tunnel infections, of the PD catheter, Moncrief and Popovich developed a two-step implantation technique in 1993 [1]. This is a popular method of initiating the PD procedure in Japan [2]. First, during PD catheter implantation, the distal end of the catheter with the cuff is buried under the skin. Second, the distal end of the PD catheter is exteriorized on PD initiation. This method is believed to reduce complications due to infection and dialysis fluid leakage on PD initiation. When this method was used in PD patients, $10.7 \%$ of cases lacked patency on exteriorization because of a fibrin plug, kinking, or omental wrap; $1.6 \%$ developed incisionsite and tunnel infections; $1.6 \%$ complained of exit-site leakage; and $0.8 \%$ experienced peritonitis [3]. Bowel perforation by the PD catheter is a serious complication that has been reported to occur in 1.3 to $1.6 \%$ of patients during PD [4].

Herein, we present a case of an unusual interaction between the PD catheter and the sigmoid colon through the side hole of the catheter, possibly caused by mechanical compression of the catheter implanted using the Moncrief-Popovich technique before PD initiation.

\section{Case presentation}

A 57-year-old woman with autosomal-dominant polycystic kidney disease (ADPKD) was treated at our hospital. As her renal function gradually declined, under laparoscopic guidance, a standard double-cuff, swan neck, straight PD catheter (JB-5(A), Hayashidera, Japan) was embedded using the Moncrief-Popovich technique. Nine months after the implantation, she was admitted to our hospital to initiate continuous ambulatory peritoneal dialysis (CAPD) therapy. When the distal end of the PD catheter was exteriorized, a brown fluid mixed with fluffy material was found in the catheter. She also complained of a small amount of watery diarrhea and abdominal pain around her pubis, and her body temperature increased to $38.3^{\circ} \mathrm{C}$ after the exteriorization. Computed tomography (CT) without a contrast medium was performed (Fig. 1a), assuming that bowel perforation, bacterial peritonitis, and mechanical stress of the PD catheter occurred due to the exteriorization. This imaging showed that there were no abnormalities in her bowel and the tip of PD catheter was intrapelvic. She was started on PD therapy after sulbactam/ampicillin administration for 4 days. Immediately after $1 \mathrm{~L}$ of PD fluid flowed into her abdominal cavity, she complained of watery diarrhea. Thus, we decided to perform CT peritoneography with $1 \mathrm{~L}$ dialysate (Dianeal $\mathrm{N}$ PD-2, Baxter, Tokyo) containing $20 \mathrm{~mL}$ Omnipaque 300 (Daiichi-Sankyo, Tokyo) [5-7]. This diagnostic imaging technique revealed an outflow of the contrast medium

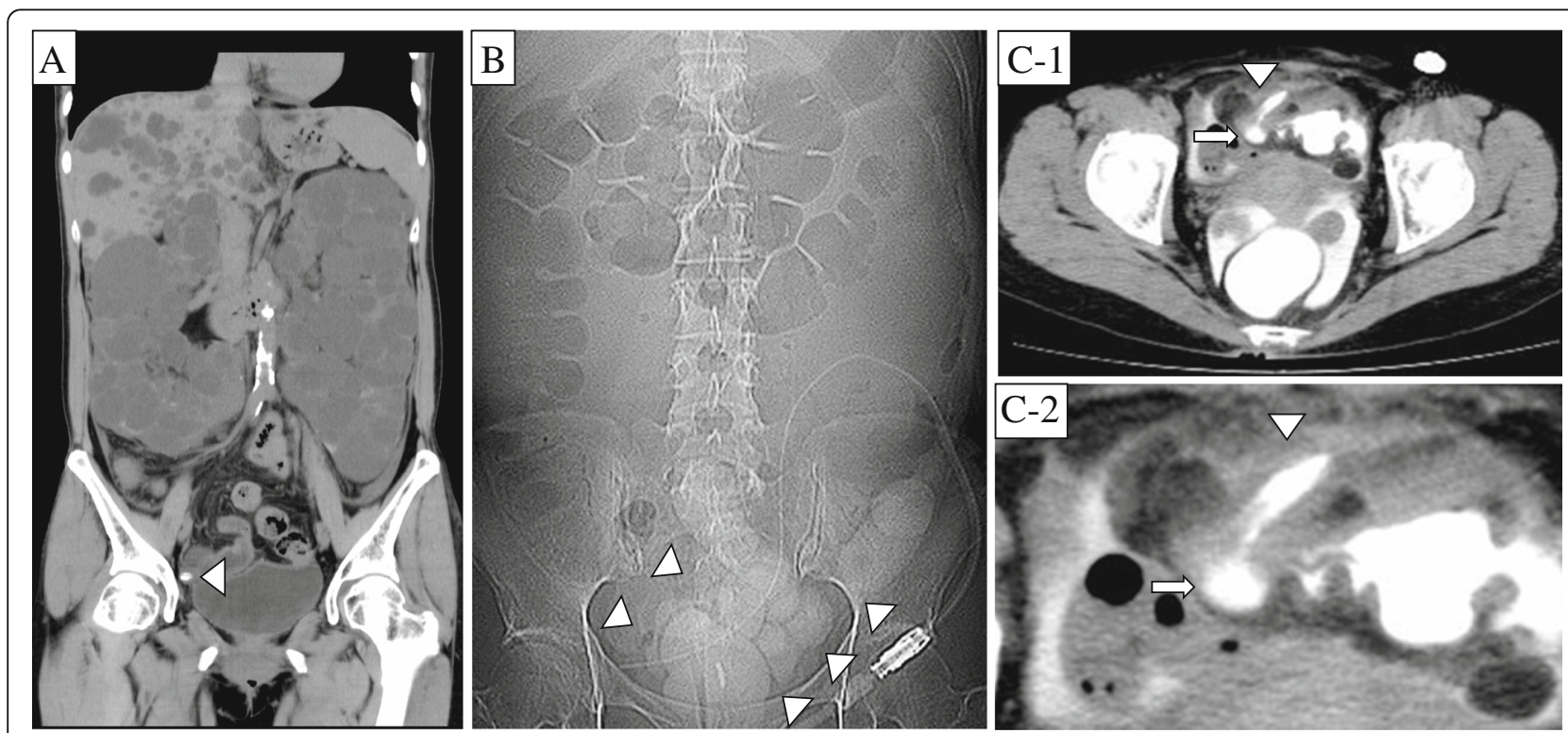

Fig. 1 PD catheter and colon interaction diagnosed by CT peritoneography. a The tip of PD catheter (arrow head) was intrapelvic. The enlarged kidney occupied a major portion of the pelvic cavity (CT without a contrast medium, coronal view). b PD fluid containing contrast media injected from the PD catheter is found in the lumen of the sigmoid colon and the rectum (CT peritoneography, scout view). c PD catheter interacting with the sigmoid colon. Contrast media injected through the PD catheter (arrowhead) flows into the luminal side of the sigmoid colon (arrow) through a hole (top: CT peritoneography, horizontal image, bottom: magnification of lesion) 
into the luminal side of the sigmoid colon through the PD catheter's side hole, suggesting an interaction between the PD catheter and the colon (Fig. 1b, c). An exploratory laparotomy conducted the same day revealed that the PD catheter had not penetrated the colon. Instead, the lateral side of the PD catheter ( $5 \mathrm{~cm}$ from the tip) had adhered to the serosal surface of the sigmoid colon, and a small orifice was observed at the corresponding location of the side hole of the catheter (Fig. 2b). This lesion was entirely surrounded by fibrous tissue, which prevented leakage of the bowel contents (Fig. 2a). Her small intestine was also attached to the PD catheter via a serosal erosion (Fig. 2c). These findings strongly suggested that this direct interaction of the PD catheter with the colon arose as a result of persistent mechanical compression of the PD catheter at one location on the colon surface accompanied by protective reactions during the period from implantation to externalization of the distal end of the PD catheter. After restoring the colon with a sigmoidectomy and colostomy, the patient was treated with hemodialysis. Seven months later, she underwent closure of the colostomy.

\section{Discussion and conclusions}

In this unusual case, bowel perforation by a PD catheter occurred asymptomatically during PD catheter embedding, which was ultimately diagnosed by CT peritoneography. Table 1 shows the clinical features of 33 case reports detailing delayed bowel perforation by PD catheters $[4,8-31]$. The clinical manifestations of delayed bowel perforation by PD catheters were heterogeneous and included symptoms such as peritonitis, watery diarrhea, catheter protrusion from the anus, and feculent eluent from the catheter. In our case, the patient experienced watery diarrhea, abdominal pain, and feculent eluent, which was consistent with the results of previous reports of bowel perforation by PD catheters. Among 24 cases in which the duration from catheter insertion to bowel perforation was known, bowel perforations occurred within 12 months in 12 cases (50\%) and 24 months in 19 cases (79\%). The sites of bowel perforations ranged from the jejunum to the rectum, with 13 out of 17 colon cases (76\%) occurring at the sigmoid colon.

We found two types of perforations reported. The first was erosion caused by the catheter side wall $(n=7)$, and the second was penetration by the PD catheter tip $(n=$ 14) (Table 1). Interestingly, three ADPKD cases, including our case, were of the erosion type and only one case was the penetration type. We speculated that an enlarged kidney could be a risk factor for bowel erosion by PD catheters because the enlarged kidney occupied a major portion of the pelvic cavity, thereby compressing the PD catheter against the sigmoid colon through which solid stool passes. Further studies on bowel erosion by PD catheters are required.

CT peritoneography is a diagnostic imaging technique used to examine the interaction of the peritoneal cavity with other internal spaces. This technique is quite useful in detecting interactions between the peritoneal and pleural spaces through the diaphragm by infusing PD fluid containing an iodine contrast agent into the abdominal cavity [5-7]. In our case, this technique was helpful in detecting the patient's bowel perforation before an exploratory laparoscopy was performed. Other methods, including exploratory laparotomy, colonoscopy, and contrast fluoroscopy, have been reported to be useful in the diagnosis of bowel perforations $[16,21]$. Among them, CT peritoneography is considered superior to conventional methods in terms of the rapid and accurate identification of the perforation site with minimal invasiveness. Markel et al. [26] have reported that CT peritoneography could reveal an interaction between
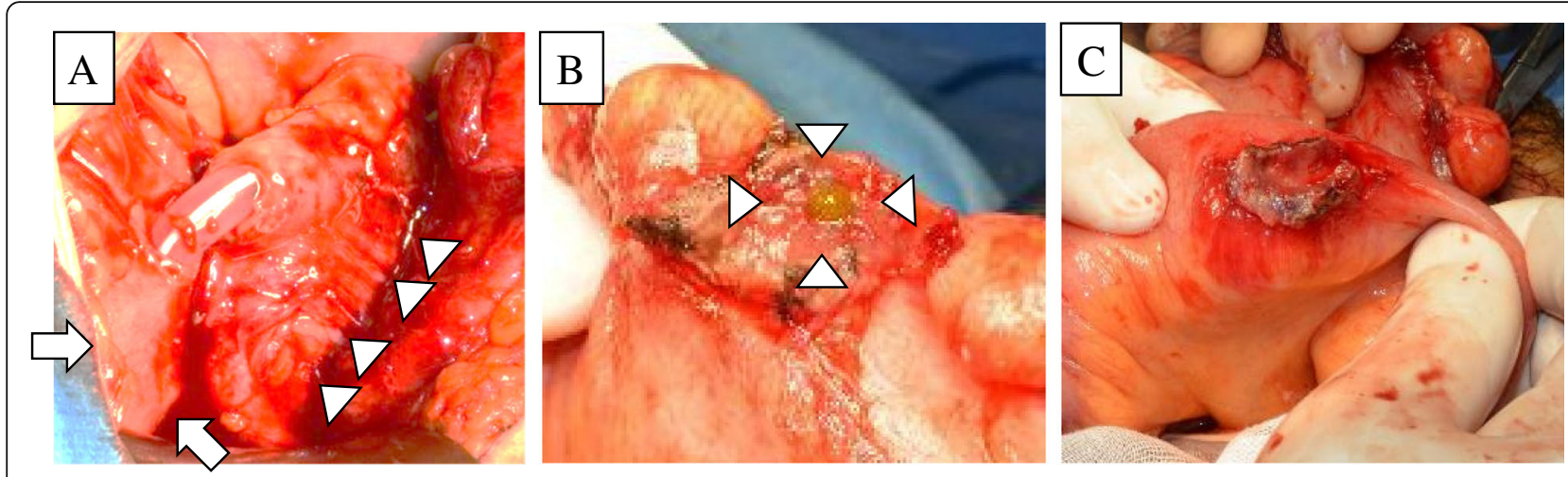

Fig. 2 Exploratory laparotomy reveals a small orifice in the eroding surface of the sigmoid colon formed where the side hole of the catheter is attached to the colon. a The PD catheter was wrapped in the omentum (arrow), and there was erosion on the sigmoid colon (arrowhead). The lateral side of the PD catheter was adhered to the sigmoid colon $5 \mathrm{~cm}$ from the catheter tip. $\mathbf{b}$ A small hole with oozing feces was found where the side hole of the catheter was attached to the colon. The lesion was entirely surrounded by fibrous tissues, which prevented leakage of the intraluminal contents. c The PD catheter was also attached to the serosa of the small intestine 
Table 1 Literature review of delayed bowel penetration or erosion caused by peritoneal dialysis (PD) catheters

\begin{tabular}{|c|c|c|c|c|c|c|c|c|c|}
\hline Age/sex & $\begin{array}{l}\text { Renal } \\
\text { disease }\end{array}$ & $\begin{array}{l}\text { Duration } \\
\text { of PD } \\
\text { (months) }\end{array}$ & $\begin{array}{l}\text { Inactive } \\
\text { use time } \\
\text { (months) }\end{array}$ & $\begin{array}{l}\text { Clinical } \\
\text { manifestation }\end{array}$ & $\begin{array}{l}\text { Diagnostic } \\
\text { methods }\end{array}$ & $\begin{array}{l}\text { Site of bowel } \\
\text { perforation }\end{array}$ & $\begin{array}{l}\text { Catheter part } \\
\text { interacting with } \\
\text { the bowel }\end{array}$ & $\begin{array}{l}\text { Erosion or } \\
\text { penetration }\end{array}$ & Ref. \\
\hline $71 / \mathrm{M}$ & GN & 9 & 0 & Peritonitis & EL & Sigmoid colon & NA & NA & [8] \\
\hline $46 / \mathrm{M}$ & PKD & NA & 4 & Asymptomatic & Sonogram & Rectum & Тip & Penetration & [9] \\
\hline $42 / M$ & GN & 48 & 1.6 & Peritonitis & EL & Small bowel & NA & NA & [10] \\
\hline $22 / \mathrm{M}$ & PSG & 8 & NA & Peritonitis & EL & Sigmoid colon & NA & NA & [11] \\
\hline $69 / F$ & PKD & 8 & NA & Peritonitis & EL & Sigmoid colon & NA & NA & [11] \\
\hline $36 / \mathrm{M}$ & $\lg A N$ & 51 & NA & Peritonitis & EL & Right colon & NA & NA & [11] \\
\hline $80 / \mathrm{M}$ & $\mathrm{HN}$ & 8 & NA & Peritonitis & CF & Sigmoid colon & NA & NA & [11] \\
\hline $54 / \mathrm{M}$ & $\mathrm{RT}+\mathrm{HP}$ & 15 & NA & Peritonitis & EL & Sigmoid colon & NA & NA & [11] \\
\hline $54 / F$ & DKD & 3 & NA & Peritonitis & EL & Ileum/cecum & NA & NA & [11] \\
\hline $53 / F$ & IN & 17 & NA & Peritonitis & EL & Sigmoid colon & NA & NA & [11] \\
\hline 78/M & $\mathrm{HN}$ & 24 & 0 & Peritonitis & Contrast enema & Proximal jejunum & NA & NA & [12] \\
\hline $43 / \mathrm{M}$ & MPGN & 5 & 26 & $\begin{array}{l}\text { Catheter protrusion } \\
\text { (anus) }\end{array}$ & Clinical manifestation & NA & $\begin{array}{l}\text { Catheter protrusion } \\
\text { (anus) }\end{array}$ & Penetration & [4] \\
\hline $46 / \mathrm{M}$ & GN & 21 & 0 & Rectal hemorrhage & Colonoscopy & Cecum & Side wall & Erosion & [13] \\
\hline $74 / \mathrm{M}$ & NA & 10 & 8 & Watery diarrhea & CF & Sigmoid colon & Tip & Penetration & {$[14]$} \\
\hline $36 / \mathrm{M}$ & NA & 54 & 6 & Foul smell & Colonoscopy & NA & NA & NA & [15] \\
\hline $62 / F$ & NA & 3 & 3 & $\begin{array}{l}\text { Peritonitis with } \\
\text { diarrhea and } \\
\text { feculent effluent }\end{array}$ & $C F$ & Transverse colon & Тip & Penetration & [16] \\
\hline 73/M & MGUS, HN & NA & NA & Watery diarrhea & $\mathrm{CF}$ and $\mathrm{EL}$ & Rectum & Тір & Penetration & {$[17]$} \\
\hline 18/M & MN & 10 & 4 & $\begin{array}{l}\text { Catheter protrusion } \\
\text { (anus) }\end{array}$ & EL & Rectosigmoid junction & $\begin{array}{l}\text { Catheter protrusion } \\
\text { (anus) }\end{array}$ & Penetration & [18] \\
\hline $2 / \mathrm{M}$ & PKD & 1.5 & 1.5 & Fluid instilled & CF & Small intestine & NA & Erosion & [19] \\
\hline $54 / \mathrm{M}$ & DKD & 6.5 & 0 & Watery diarrhea & CT & Appendix & NA & NA & [20] \\
\hline $31 / M$ & $\begin{array}{l}\text { Polyarteritis } \\
\text { nodosa }\end{array}$ & 24 & 8 & $\begin{array}{l}\text { Catheter protrusion } \\
\text { (anus) }\end{array}$ & CT & Sigmoid colon & $\begin{array}{l}\text { Catheter protrusion } \\
\text { (anus) }\end{array}$ & Penetration & [21] \\
\hline $50 / \mathrm{M}$ & DKD & 18 & 6 & $\begin{array}{l}\text { Peritonitis with } \\
\text { watery diarrhea }\end{array}$ & CT & Rectum & Tip & Penetration & [22] \\
\hline $72 / \mathrm{M}$ & GN & 27 & 48 & $\begin{array}{l}\text { Catheter protrusion } \\
\text { (anus) }\end{array}$ & $\mathrm{CT}$ and colonoscopy & Rectum & $\begin{array}{l}\text { Catheter protrusion } \\
\text { (anus) }\end{array}$ & Penetration & [23] \\
\hline 44/M & GN & 3 & 0 & Peritonitis & CT peritoneography & Jejunum & Side wall & Erosion & [24] \\
\hline 68/M & DKD & 14 & 0 & $\begin{array}{l}\text { Catheter protrusion } \\
\text { (anus) }\end{array}$ & CT & Sigmoid colon & $\begin{array}{l}\text { Catheter protrusion } \\
\text { (anus) }\end{array}$ & Penetration & [25] \\
\hline 6/M & Renal dysplasia & 3 & 0 & Feculent effluent & CT peritoneography & Unknown & Unknown & Erosion & [26] \\
\hline $11 / \mathrm{M}$ & Renal dysplasia & 6 & 3 & $\begin{array}{l}\text { Catheter protrusion } \\
\text { (anus) }\end{array}$ & Laparoscopy & Sigmoid colon & $\begin{array}{l}\text { Catheter protrusion } \\
\text { (anus) }\end{array}$ & Penetration & [27] \\
\hline $53 / F$ & DKD & 0 & 4 & Feculent effluent & $\mathrm{CT}$ peritoneography and $\mathrm{EL}$ & Sigmoid colon & Side wall & Erosion & [28] \\
\hline $57 / F$ & PKD & 0 & 7 & $\begin{array}{l}\text { Peritonitis with } \\
\text { watery diarrhea }\end{array}$ & $\mathrm{CT}$ peritoneography and EL & Rectum & Side wall & Erosion & [28] \\
\hline 65/M & $\begin{array}{l}\text { Bilateral } \\
\text { hydronephrosis }\end{array}$ & 24 & 0 & Watery diarrhea & Laparoscopy & Sigmoid colon & Тір & Penetration & [29] \\
\hline 78/M & $\mathrm{HN}$ & 5 & 0 & $\begin{array}{l}\text { Peritonitis with } \\
\text { watery diarrhea }\end{array}$ & EL & Small bowel & Tip & Penetration & [30] \\
\hline 92/M & GN & 5 & 0 & $\begin{array}{l}\text { Bile and bowel } \\
\text { contents in the } \\
\text { PD effluent }\end{array}$ & Autopsy & Jejunum & Тір & Penetration & [31] \\
\hline $57 / F$ & PKD & 0 & 9 & $\begin{array}{l}\text { Peritonitis with } \\
\text { diarrhea and } \\
\text { feculent effluent }\end{array}$ & CT peritoneography & Sigmoid colon & Side wall & Erosion & $\begin{array}{l}\text { Present } \\
\text { case }\end{array}$ \\
\hline
\end{tabular}

GN glomerulonephritis, EL exploratory laparotomy, NA not available, PKD polycystic kidney disease, PSG post-streptococcal glomerulonephritis, IgAN IgA nephropathy, HN hypertensive nephrosclerosis, CF contrast fluoroscopy, RT renal tuberculosis, HP hypertension, DKD diabetic kidney disease, IN interstitial nephritis, MPGN membranoproliferative glomerulonephritis, MGUS monoclonal gammopathy of uncertain significance, MN membranous nephritis, CT computed tomography, $P D$ peritoneal dialysis 
the PD catheter and the colon, which was not observed during laparotomy.

Bowel perforation typically occurs at the time of PD catheter insertion. This complication is uncommon during other procedures [12]. Delayed bowel perforation usually involves a dormant PD catheter $[16,21]$ and has also been reported during ongoing PD therapy (Table 1). Our case had several symptoms that would indicate a bowel perforation, and no inflammatory symptoms were apparent in the laboratory data from catheter implantation to PD initiation. Feculent eluent was observed in the PD catheter on exteriorization of the distal end when the patient complained of watery diarrhea and abdominal pain, which is consistent with symptoms previously reported after bowel perforation by a PD catheter [14].

An exploratory laparotomy revealed a small orifice on the eroded surface of the sigmoid colon that formed where the side hole of the catheter was attached to the colon. In addition, the PD catheter was wrapped in the omentum, and the erosion of the sigmoid colon was surrounded by fibrous tissues. This protective reaction is believed to require time, indicating that the lateral side of the PD catheter could have eroded the bowel wall, which resulted in a perforation due to the persistent mechanical compression of the PD catheter at one location over a long duration. This continuous pressure causes localized ischemia which eventually leads to the formation of a decubitus erosion, laceration, or frank perforation [32].

The risk factors for bowel perforation by PD catheters have been previously reported and include the use of immunosuppressants, the presence of diverticulitis [12], colonic amyloidosis [17], and a lack of fluid in the peritoneal cavity after cessation of continuous ambulatory PD because of an immobile catheter [16, 21]. A lengthy implantation of the PD catheter may be involved in this complication, although the optimal time interval from peritoneal catheter insertion to PD initiation has not been established yet. In our case, a lack of fluid in the peritoneal cavity and possible diverticulitis might have contributed to the patient's bowel perforation although there were only a few complications of diverticulum. The patient's enlarged kidney caused by ADPKD might also have been involved in the compression of the PD catheter into the sigmoid colon. Defecation control should be strengthened, or preoperative abdominal pressure/intra-abdominal pressure (IAP) monitoring should be considered when using Moncrief-Popovich technique with particular ADPKD patient.

In conclusion, a bowel perforation caused by an embedded PD catheter is a rare but possible complication even when using the Moncrief-Popovich technique. Watery diarrhea following a CAPD exchange is a particularly important clinical sign that indicates bowel perforation by a PD catheter. CT peritoneography may be helpful in identifying the bowel perforation site with minimal invasiveness.

\section{Abbreviations}

ADPKD: Autosomal-dominant polycystic kidney disease; CAPD: Continuous peritoneal dialysis; PD: Peritoneal dialysis

\section{Acknowledgements}

We are grateful to the members of the Department of Urology and the Blood Purification Center of Kitano Hospital.

Funding

Not applicable

\section{Availability of data and materials}

All data analyzed during this study are included in this published article.

\section{Authors' contributions}

TH wrote the initial draft and designed this study. HS and TT contributed to the critical revision. HM and $\mathrm{HT}$ performed and interpreted the exploratory laparotomy. All authors read and approved the final manuscript.

\section{Ethics approval and consent to participate}

All procedures in this study were performed in accordance with the ethical standards of the institutional and/or national research committee at which the studies were conducted and in accordance with the 1964 Helsinki declaration and its later amendments or comparable ethical standards. Informed consent was obtained from our patient.

\section{Consent for publication}

Not applicable

\section{Competing interests}

The authors declare that they have no competing interests.

\section{Publisher's Note}

Springer Nature remains neutral with regard to jurisdictional claims in published maps and institutional affiliations.

\section{Author details}

'Department of Nephrology, Graduate School of Medicine, Kyoto University, Kyoto, Japan. ${ }^{2}$ Department of Nephrology and Dialysis, Kitano Hospital, Tazuke Kofukai Medical Research Institute, Osaka, Japan. ${ }^{3}$ Department of Surgery, National Hospital Organization Himeji Medical Center, Himeji, Japan. ${ }^{4}$ Department of Gastroenterological Surgery and Oncology, Kitano Hospital, Tazuke Kofukai Medical Research Institute, Osaka, Japan.

Received: 1 February 2019 Accepted: 29 April 2019

Published online: 31 May 2019

\section{References}

1. Moncrief JW, Popovich RP, Broadrick LJ, He ZZ, Simmons EE, Tate RA. The Moncrief-Popovich catheter. A new peritoneal access technique for patients on peritoneal dialysis. ASAIO J. 1993;39(1):62-5.

2. Kubota M, Kanazawa M, Takahashi Y, lo H, Ishiguro N, Tomino Y. Implantation of presternal catheter using Moncrief technique: aiming for fewer catheter-related complications. Perit Dial Int. 2001;21(Suppl 3):S205-8.

3. Elhassan E, McNair B, Quinn M, Teitelbaum I. Prolonged duration of peritoneal dialysis catheter embedment does not lower the catheter success rate. Perit Dial Int. 2011;31(5):558-64.

4. Jansen GP, Gerlag PG, Bruyninckx BC. Unusual presentation of bowel perforation by a CAPD catheter. Perit Dial Int. 1994;14(2):180-2.

5. Hollett MDM, S C, Ellis JH, Francis IR, Swartz RD. Complications of continuous ambulatory peritoneal dialysis: evaluation with $\mathrm{CT}$ peritoneography. Am J Roentgenol. 1992;159(5):983-9.

6. Hawkins SP, Homer JA, Murray BB, Voss DM, van der Merwe WM. Modified computed tomography peritoneography: clinical utility in continuous ambulatory peritoneal dialysis patients. Australas Radiol. 2000;44(4):398-403.

7. Xu T, Xie J, Wang W, Ren H, Chen N. Peritoneal-pleural leaks demonstrated by CT peritoneography. Case Rep Nephrol Dial. 2015;5(2):135-9.

8. Watson LC, Thompson JC. Erosion of the colon by a long-dwelling peritoneal dialysis catheter. JAMA. 1980;243(21):2156-7.

9. Jamison MH, Fleming SJ, Ackrill P, Schofield PF. Erosion of rectum by Tenckhoff catheter. Brit J Surg. 1988;75(4):360. 
10. Rambausek M, Zeier M, Weinreich T, Ritz E, Rau J, Pomer S. Bowel perforation with unused Tenckhoff catheters. Perit Dial Int. 1989;9(1):82.

11. Rotellar C, Sivarajan S, Mazzoni MJ, Aminrazavi M, Mosher WF, Rakowski TA, et al. Bowel perforation in CAPD patients. Perit Dial Int. 1992;12(4):396-8.

12. Korzets Z, Golan E, Ben-Dahan J, Neufeld D, Bernheim J. Decubitus smallbowel perforation in ongoing continuous ambulatory peritoneal dialysis. Nephrol Dial Transpl. 1992;7(1):79-81.

13. Balaji V, Digard N, Wise MH. Delayed bowel erosion due to functioning chronic ambulatory peritoneal dialysis catheter. Nephrol Dial Transpl. 1996. 11(2):368-9.

14. Shrestha BM, Wilkie M, Raftery AT. Delayed colonic perforation caused by an unused CAPD catheter in a patient presenting with diarrhea. Perit Dial Int. 2003;23(6):610-1.

15. Borazan A, Ustun H, Akkas M, Ozbay O, Yilmaz A. Bowel perforation during catheter removal after the sixth month of peritoneal dialysis termination. Acta Medica Int. 2003;46(2):77-8.

16. Grzegorzewska AE. Perforation of the transverse colon caused by a permanent peritoneal dialysis catheter. Perit Dial Int. 2004;24(3):298.

17. Finkle SN. Peritoneal dialysis catheter erosion into bowel: amyloidosis may be a risk factor. Perit Dial Int. 2005;25(3):296-7.

18. Saweirs WW, Casey J. Asymptomatic bowel perforation by a Tenckhoff catheter. Perit Dial Int. 2005;25(2):195-6.

19. Askenazi D, Katz A, Tenney F, Benfield M, Barnhart D. An unusual case of peritoneal dialysis malfunction. Kidney Int. 2007;72(4):524.

20. George J, Varma S, Gopi SP, Ramachandran S, Thampi M, Kunjukunju M, et al. Quiz page. Perforation of a functioning Tenckhoff catheter through the appendix. Am J Kidney Dis. 2008;52(1):A47-8.

21. Trivedi H, Tan HP, Morgan C, Shapiro R, Basu A. Colonic perforation by a dormant peritoneal dialysis catheter post renal transplantation. Am Surg. 2010;76(8):908-9.

22. Baek SK, Bae OS, Jang BK. Endoscopic management of delayed perforation of the rectum caused by a peritoneal dialysis catheter. Surg Laparo Endo Per. 2011;21(1):e44-7.

23. Wang R, Chen Z, Wang J, Zhang X, Shou Z, Chen J. Delayed bowel perforation in a peritoneal dialysis patient: a case report and literature review. Perit Dial Int. 2014;34(4):460-6.

24. Ramanarayanan S, Gupta S, Vuthaluru S, Gamanagatti S. Small-bowe erosion by a functioning peritoneal dialysis catheter. Perit Dial Int. 2014; 34(1):124-7.

25. Chu PY, Siu KL. A rare but serious complication of continuous ambulatory peritoneal dialysis: delayed perforation of the colon by the Tenckhoff catheter. Hong Kong Med J. 2016;22(3):286-8.

26. Markel TA, West KW. Management of peritoneal dialysis catheters that erode into bowel: two pediatric case reports and a review of the literature. Perit Dial Int. 2016;36(6):680-4.

27. Maxted AP, Davies B, Colliver D, Williams A, Lunn A. Peritoneal dialysis catheter removal post-transplant - a rare case of delayed bowel perforation. Perit Dial Int. 2017;37(6):650-1.

28. Fujiwara M, Soda T, Okada T, Kanamaru H, Inoue T, Ogawa O. Bowel perforation by a peritoneal dialysis catheter: report of two cases. BMC Nephrol. 2017;18(1):312.

29. Quinto Ruiz J, Duron Gutierrez CE, Romero Moreno AH, Gonzalez Rosas S, Castaneda Gutierrez AD. Erosion of a Tenckhoff catheter to the sigmoid colon: an uncommon delayed complication. CEN Case Rep. 2017;6(2):129-31.

30. Shima H, Mizoguchi S, Morine Y, Tashiro M, Okada K, Minakuchi J, et al. Intestinal perforation by a peritoneal dialysis catheter in which fungal peritonitis led to diagnosis: a rare case report. CEN Case Rep. 2018;7(2):208-10.

31. Yao J, Witherspoon L, McCormick BB, Belanger E, Warren JE. Abdominal visceral perforation by buried peritoneal dialysis catheters: cause or coincidence? Semin Dial. 2018;31(3):305-8.

32. Kagan A, Bar-Khayim Y. Delayed decubitus perforation of the bowel is a sword of damocles in patients on peritoneal dialysis. Nephron. 1996;74(1):232-3.

Ready to submit your research? Choose BMC and benefit from:

- fast, convenient online submission

- thorough peer review by experienced researchers in your field

- rapid publication on acceptance

- support for research data, including large and complex data types

- gold Open Access which fosters wider collaboration and increased citations

- maximum visibility for your research: over $100 \mathrm{M}$ website views per year

At BMC, research is always in progress.

Learn more biomedcentral.com/submissions 